\title{
ANALISIS PENENTUAN LOKASI PARKIR PADA KAWASAN PERDAGANGAN SINGOSAREN KOTA SURAKARTA BERDASARKAN PREFERENSI PENGUNJUNG
}

\author{
Fauzi Nuraninda Haqie ${ }^{1}$, Soedwiwahjono ${ }^{1}$, Kuswanto Nurhadi ${ }^{2}$ \\ 1Program Studi Perencanaan Wilayah dan Kota Fakultas Teknik Universitas Sebelas Maret Surakarta \\ 2Program Studi Teknik Sipil Fakultas Teknik Universitas Sebelas Maret Surakarta
}

\begin{abstract}
Abstrak
Kawasan perdagangan Singosaren merupakan salah satu kawasan yang menjadi tarikan perjalanan. Hal ini menyebabkan timbulnya kebutuhan ruang parkir pada kawasan tersebut dikarenakan mayoritas masyarakat Kota Surakarta menggunakan kendaraan pribadi dalam melakukan mobilitas. Fakta di lapangan menunjukkan bahwa 99\% parkir pada kawasan tersebut merupakan parkir on street. Selain itu pada kawasan perdagangan Singosaren akan diterapkan konsep walking street yang salah satu substansi penataannya adalah dengan menjadikan kawasan Singosaren menjadi kawasan yang steril dari parkir on street. Penelitian ini bertujuan untuk mendapatkan dimana alternatif-alternatif lokasi parkir yang dapat memenuhi kebutuhan kawasan perdagangan Singosaren berdasarkan preferensi pengunjung kawasan tersebut. Preferensi pengunjung juga digunakan untuk menentukan kriteria lokasi parkir mana yang paling tinggi tingkat kepentingannya hingga paling rendah tingkat kepentingannya. Penelitian ini merupakan penelitian kuantitatif dengan menggunakan teknik analisis skoring untuk penentuan alternatif lokasi parkir dan teknik pembobotan kriteria lokasi parkir berdasarkan preferensi pengunjung. Teknik pengumpulan data dengan observasi dan penyebaran kuesioner pada pengunjung kawasan perdagangan Singosaren. Hasil dari penelitian ini didapatkan bahwa berdasarkan preferensi pengunjung kawasan perdagangan Singosaren urutan kriteria yang memiliki bobot paling tinggi kepentingannya hingga paling rendah kepentingannya adalah (1) keamanan; (2) jarak berjalan; (3) aksesibilitas; (4) ketersediaan lahan/ruang; (5) rencana tata ruang; (6) lingkungan. Berdasarkan analisis dengan teknik skoring didapatkan 5 alternatif lokasi parkir yaitu lahan kosong utara Matahari Departement Store (lokasi A) yang tergolong dalam kategori kurang sesuai untuk lokasi parkir. Kemudian lahan kosong barat Matahari Departement Store (lokasi B), lahan kosong timur Lapangan Kartopuran (lokasi C), Lapangan Kartopuran (lokasi D), dan ruang parkir Matahari Departement Store (lokasi E) yang tergolong dalam kategori sesuai untuk lokasi parkir. Setiap alternatif lokasi tersebut memiliki kekurangan dan kelebihan berdasarkan kriteria lokasi parkir yang telah dihimpun dalam penelitian ini.
\end{abstract}

Kata kunci : lokasi parkir; parkir; preferensi pengunjung

\begin{abstract}
Singosaren commercial area is part of the city that became trip attraction. This fenomena leads to increasing demands parking space in this area, because of majority of Surakarta citizen were using private transportation to their mobility. Furthermore, it show that $99 \%$ of parking activity in this area is on-street parking. Moreover, at Singosaren commercial area will be applied the concept of walking street, which one of substance of the arrangement is to make Singosaren area into a free parking on street area.This research aims to get alternatives parking locations which could meet the needs of Singosaren Commercial area based on visitors preference. Visitor preferences also used to determine which parking location criteria are the highest level of importance to the lowest level of importance. This research is a quantitative research using scoring analysis technique for determination of alternative parking location and weighting technique of parking location criteria based on visitors preference. Technique of collecting data are observation and questioner to visitors of Singosaren commercial area. Result of this research are criteria of parking location based on Singosaren Commercial area visitors preference from the highest to the lowest importance were in order: (1) Safety; (2) Walking distance; (3) Accessibility; (4) Availability of land/space; (5) Spatial Planning; (6) Neighborhood. Based on the result of scoring analysis, 5 parking space alternatives were obtained, which are surface at north Matahari Departement Store (location A) which classified in less suitable category for parking location. Then surface at west Matahari Departement Store (location B), surface at east Lapangan Kartopuran (location C), Lapangan Kartopuran (location D), and parking area of Matahari Departement Store (location E) which classified of category suitable for parking location. Each alternative location has disadvantages and advantages based on parking location criteria that have been collected in this study.
\end{abstract}

Keywords: parking location; parking; visitor preference 


\section{PENDAHULUAN}

Kawasan perdagangan merupakan salah satu kawasan yang menjadi tarikan perjalanan. Salah satu kawasan perdagangan di Surakarta yang dominan adalah Kawasan Singosaren. Kawasan perdagangan Singosaren terletak pada koridor Jalan Gatot Subroto, Dr. Radjiman, Yos Sudarso. Hal ini menyebabkan timbulnya kebutuhan ruang parkir pada kawasan tersebut dikarenakan mayoritas masyarakat Kota Surakarta menggunakan kendaraan pribadi dalam melakukan mobilitas. Fakta di lapangan, mayoritas parkir yang ada di kawasan perdagangan Singosaren menggunakan parkir on street. Hal ini juga didukung dengan data dari UPTD Perparkiran Kota Surakarta bahwa 99\% parkir pada kawasan perdagangan Singosaren merupakan parkir on street.

Besarnya peningkatan kendaraan pribadi yang tidak diimbangi dengan peningkatan luasan jalan, tentu akan mengakibatkan penumpukan kendaraan dan jalan akan menjadi jenuh. Sebagian badan jalan yang dialihfungsikan sebagai ruang parkir dapat menyebabkan terjadinya hambatan mobilitas arus lalu lintas hingga mengakibatkan kemacetan (Miro, 2012). Keberadaan parkir on street pada kawasan tersebut berdampak pada semakin berkurangnya luas jalan yang dapat digunakan untuk sirkulasi kendaraan, sehingga kawasan tersebut menjadi kawasan padat dan sering mengalami kemacetan.

Selain itu, menurut rencana dari Dinas Pekerjaan Umum dan Penataan Ruang Kota Surakarta (yang sudah tertuang dalam DED), koridor Jalan Gatot Subroto dan Dr. Radjiman akan dikembangan dengan konsep "walking street". Konsep walking street akan diterapkan dengan pembangunan pedestrian, street furniture, perbaikan saluran drainase, penataan PKL, dan pemasangan kabel bawah tanah untuk kabel telepon dan listrik. Kemudian kawasan tersebut akan digunakan untuk mewadahi kegiatan perdagangan kecil dan menengah seperti UMKM kreatif. Direncanakan pula kawasan ini nantinya dapat menjadi kawasan yang steril dari parkir on street. Dalam RDTR Kota Surakarta, dijelaskan bahwa pemilihan lokasi parkir ditentukan dengan berbagai pertimbangan penempatan lokasi parkir juga harus mempertimbangkan kebutuhan dan kepentingan seluruh pihak terkait terutama bagi masyarakat, sehingga tidak hanya mementingkan kepentingan pemerintah semata.

Dari penjabaran-penjabaran tersebut maka dibutuhkan penelitian mengenai dimana alternatif lokasi parkir yang sesuai sehingga dapat mengakomodasi kebutuhan pada kawasan perdagangan Singosaren berdasarkan preferensi pengunjung. Tujuan dari penelitian ini adalah untuk menentukan alternatif lokasi parkir yang dapat mengakomodasi kebutuhan pada kawasan perdagangan Singosaren berdasarkan preferensi pengunjung.

\section{KAJIAN TEORI}

\subsection{KEBUTUHAN RUANG PARKIR}

Salah satu metode untuk menentukan kebutuhan ruang parkir adalah berdasarkan akumulasi parkir maksimum (Budiman dalam Rochman, 2013). Metode ini memperhitungkan kebutuhan parkir berdasarkan akumulasi tertinggi kendaraan parkir pada selang waktu pengamatan. Metode ini akan dapat menentukan kebutuhan ruang parkir maksimum. Metode ini membutuhkan pengamatan langsung di lapangan yaitu dengan teknik survey patroli parkir untuk mengetahui jumlah akumulasi tertinggi kendaraan parkir (Hobbs, 1995).

\subsection{KRITERIA LOKASI PARKIR}

Para ahli telah merumuskan kriteria-kriteria untuk lokasi parkir yang baik. Beberapa sumber teori kriteria lokasi parkir telah dihimpun dalam penelitian ini.

Ketersediaan lahan atau ruang menjadi kriteria utama dalam lokasi parkir. Hal ini dikarenakan dalam memenuhi kebutuhan parkir harus terdapat lahan atau ruang yang memadai (Direktorat Jendral Perhubungan Darat, 1998; Whiteside, 1961). Terdapat pula larangan-larangan parkir pada tempat-tempat tertentu seperti persimpangan jalan, jalan sempit, dekat jalur pedestrian,jembatan, terowongan, underpass, dan pintu masuk bangunan (O'Flaherty, 1997). Lokasi ini dianggap dapat meningkatkan bahaya kecelakaan dan membahayakan keselamatan pengguna parkir (Hobbs, 1995). Lokasi parkir harus memperhatikan keamanan pengguna (Whiteside, 1961). Selain dari bahaya kecelakaan, keamanan juga dapat dilihat dari resiko kejadian kriminal pada kawasan tersebut (Chrest et al, 1996). 
Lokasi parkir juga harus memperhatikan jarak lokasi parkir ke kawasan yang akan dilayaninya (Whiteside, 1961). Jarak ini sebaiknya tidak lebih dari standar jarak berjalan kaki di Indonesia yaitu 400 meter (SNI 03-1733-2004). Aksesibilitas dari lokasi parkir juga merupakan hal yang penting. Lokasi parkir harus memberikan kemudahan bagi pengguna jasa untuk mencapainya (Whiteside, 1961; Hobbs, 1995; Direktorat Jendral Perhubungan Darat, 1998).

Selain kriteria-kriteria tersebut, Lokasi parkir harus memperhatikan kesesuaiannya dengan rencana tata ruang. Lokasi parkir seharusnya tidak berada pada kawasan lindung yang pemanfaataan ruangnya sebagai lokasi parkir tidak diizinkan. Lokasi parkir juga sebaiknya tidak berada pada lingkungan yang berkepadatan penduduk tinggi untuk dapat meminimalisir bahaya polusi dan pencemaran lingkungan yang ditimbulkan karena keberadaan lokasi parkir harus tetap memperhatikan kelestarian lingkungan (Direktorat Jendral Perhubungan Darat, 1998).

Dari penjabaran-penjabaran teori yang telah dihimpun dari berbagai sumber ahli tersebut, maka dapat dirumuskan kriteria lokasi parkir (variabel) yang digunakan dalam penelitian ini adalah :

(1) Ketersediaan lahan atau ruang (Direktorat Jendral Perhubungan Darat, 1998; Whiteside, 1961)

(2) Rencana umum tata ruang daerah (Direktorat Jendral Perhubungan Darat, 1998)

(3) Keamanan dan kelancaran lalu lintas (O'Flaherty, 1997; Hobbs, 1995; Chrest et al, 1996)

(4) Jarak berjalan (Whitesie, 1961; SNI 03-1733-2004)

(5) Aksesibilitas (Whiteside, 1961; Hobbs, 1995; Direktorat Jendral Perhubungan Darat, 1998)

(6) Lingkungan (Direktorat Jendral Perhubungan Darat, 1998)

\section{METODE PENELITIAN}

\subsection{PENDEKATAN DAN JENIS PENELITIAN}

Penelitian ini menggunakan pendekatan deduktif yaitu penelitian yang pendekatannya diawali pada teori dengan output mendapatkan suatu kebenaran mengenai fenomena yang terjadi di lapangan (Sugiyono, 2013). Penelitian ini menggunakan pendekatan secara deduktif dikarenakan pada penelitian ini dilakukan proses pengumpulan teori yang berkaitan dengan kriteria lokasi parkir pada kawasan perdagangan sehingga teori tersebut dapat digunakan sebagai acuan dalam pencarian data di lapangan yang nantinya akan dihasilkan alternative lokasi parkir yang sesuai dengan kebutuhan kawasan perdagangan Singosaren. Metode kuantitatif menggunakan teknik-teknik analisis statistik untuk menjawab permasalahan (Sugiyono, 2013). Dalam penelitian ini, analisis skoring dan pembobotan untuk mengetahui lokasi parkir yang sesuai pada kawasan perdagangan Singosaren.

\subsection{TEKNIK PENGUMPULAN DATA}

Pengumpulan data dilakukan dengan survey sekunder ke instansi terkait seperti Bappeda, UPTD Perparkiran Kota Surakarta, dan Kepolisian Sektor Serengan. Dan dilakukan pula survey primer dengan observasi lapangan untuk mengidentifikasikan kondisi parkir pada kawasan perdagangan Singosaren, mengidentifikasikan kebutuhan parkir, dan mengidentifikasikan kriteria-kriteria penentuan lokasi parkir. Dan penyebaran kuesioner untuk mengetahui preferensi pengunjung kawasan perdagangan Singosaren dalam kriteria lokasi parkir dengan teknik random sampling. Penyebaran kuesioner dilakukan pada 96 responden dengan rumus untuk mendapatkan sampel responden sebagai berikut (Margono dalam Sinambela, 2014) :

$$
n=\frac{z^{2} \cdot p \cdot q}{d^{2}}
$$

Keterangan :

$n=$ jumlah sampel

$z=$ nilai $z$ yang sering digunakan 1,960

$p=$ estimasi proporsi (proporsi tertinggi dengan nilai $p=0,5$ )

$q=1-p$

$d=$ tingkat kesalahan $10 \%(0,1)$ 


\subsection{TEKNIK ANALISIS DATA}

\subsubsection{ANALISIS KEBUTUHAN PARKIR KAWASAN PERDAGANGAN SINGOSAREN}

Untuk mengetahui kebutuhan parkir pada kawasan penelitian, dapat menggunakan perhitungan :

$$
\text { Kebutuhan ruang parkir }=\text { akumulasi parkir maksimum } \times \text { luas SRP }
$$

Akumulasi parker maksimum didapatkan dari survey patrol parkir yaitu menghitung jumlah kendaraan parkir pada suatu periode waktu tertentu (Hobbs, 1995). Kemudian besar luas SRP (satuan uang parkir) dapat dilihat pada table berikut.

Tabel 1. Standar Luas SRP

\begin{tabular}{|l|l|l|}
\hline No. & \multicolumn{1}{|c|}{ Jenis Kendaraan } & \multicolumn{1}{c|}{ Satuan Ruang Parkir } \\
\hline 1. & $\bullet$ Mobil penumpang golongan I & $\bullet 2.30 \times 5.00$ \\
& $\bullet$ Mobil penumpang golongan II & $\bullet 2.50 \times 5.00$ \\
& $\bullet$ Mobil penumpang golongan III & $\bullet 3.00 \times 5.00$ \\
\hline 2. & Bus / truck & $3.40 \times 12.50$ \\
\hline 3. & Motor & $0.75 \times 2.00$ \\
\hline
\end{tabular}

Sumber : Direktorat Jendral Perhubungan Darat, 1998

\subsubsection{ANALISIS KRITERIA LOKASI PARKIR}

Analisis kriteria lokasi parkir dilakukan untuk mengetahui preferensi pengunjung kawasan perdagangan Singosaren dalam menentukan kriteria lokasi parkir. Teknik analisis yang digunakan adalah pembobotan dengan metode ranking. Metode ranking dilakukan dengan cara menyusun ranking setiap variabel yang ada. Penentuan ranking ditentukan berdasarkan persepsi dan preferensi responden (Malczweski, 1999). Ranking 1 merupakan variabel yang paling tinggi tingkat kepentingannya, dan berlaku seterusnya hingga ranking 6 merupakan variabel yang tingkat kepentingannya paling rendah. Setelah responden mengurutkan ranking dari setiap variabel, selanjutnya pembobotan ditentukan dengan rumus berikut :

$$
w j=(n-r j+1) / \sum(n-r p+1) \ldots \ldots
$$

Keterangan :

$\mathrm{Wj} \quad=$ bobot normal parameter (variabel) $\mathrm{ke} \mathrm{j}$

$\mathrm{n} \quad=$ banyaknya parameter (variabel) yang dikaji

$\mathrm{rp} \quad=$ parameter (variabel)

rj = posisi ranking parameter (variabel)

Hasil dari perhitungan tersebut akan mendapatkan bobot dari tiap variabel. Bobot dari tiap variabel ini akan digunakan dalam pengukuran variabel untuk analisis penentuan lokasi parkir.

\subsubsection{ANALISIS PENENTUAN LOKASI PARKIR}

Analisis penentuan lokasi parkir dilakukan dengan teknik skoring pada setiap kriteria lokasi parkir yang telah terjabarkan ke dalam indikator dan parameter. Variabel yang pertama diidentifikasikan adalah ketersediaan lahan atau ruang untuk kemudian didapatkan lahan/ruang mana yang dapat digunakan sebagai alternatif lokasi parkir.

Tabel 2. Skor Variabel

\begin{tabular}{|l|l|l|l|l|}
\hline \multicolumn{1}{|c|}{ Variabel } & \multicolumn{1}{|c|}{ Indikator } & \multicolumn{1}{|c|}{ Paramater } & Skor & Sumber \\
\hline $\begin{array}{l}\text { Ketersediaan } \\
\text { lahan atau ruang }\end{array}$ & $\begin{array}{l}\text { Kemampuan luas lahan } \\
\text { dan atau luas ruang }\end{array}$ & $\begin{array}{l}\text { Lahan dan atau ruang mampu memenuhi } \\
\text { kebutuhan parkir dalam 1 lantai luas lahan }\end{array}$ & 2 & \multirow{2}{*}{ Teknomo (1997) } \\
\cline { 3 - 5 } & & $\begin{array}{l}\text { Lahan dan atau ruang mampu memenuhi } \\
\text { kebutuhan parkir dalam >1 lantai luas lahan }\end{array}$ & 1 & \\
\hline $\begin{array}{l}\text { Rencana umum } \\
\text { tata } \\
\text { daerah }\end{array}$ & $\begin{array}{l}\text { Kesesuaian dengan } \\
\text { rencana tata ruang }\end{array}$ & Lokasi terletak pada kawasan budidaya & 2 & Direktorat Jendral \\
\cline { 3 - 5 } & & Lokasi terletak pada kawasan lindung & 1 & $\begin{array}{l}\text { Perhubangan } \\
\text { Darat (1998) }\end{array}$ \\
\hline
\end{tabular}




\begin{tabular}{|c|c|c|c|c|}
\hline Variabel & Indikator & Paramater & Skor & Sumber \\
\hline \multirow[t]{4}{*}{ Keamanan } & \multirow{2}{*}{$\begin{array}{l}\text { Frekuensi dan jenis } \\
\text { kejadian kriminal pada } \\
\text { kawasan }\end{array}$} & Low risk facilities & 2 & \multirow{2}{*}{$\begin{array}{l}\text { Chrest et al } \\
\text { (1996) }\end{array}$} \\
\hline & & High risk facilities & 1 & \\
\hline & \multirow{2}{*}{$\begin{array}{lr}\text { Jarak } & \text { dari } \\
\text { persimpangan } & \text { jalan } \\
\text { utama } & \\
\end{array}$} & $>25$ meter & 2 & \multirow{2}{*}{$\begin{array}{l}\text { Direktorat Jendral } \\
\text { Perhubungan } \\
\text { Darat (1998) } \\
\end{array}$} \\
\hline & & $0-25$ meter & 1 & \\
\hline \multirow[t]{2}{*}{ Jarak berjalan } & \multirow{2}{*}{$\begin{array}{l}\text { Standar jangkauan } \\
\text { jarak berjalan kaki }\end{array}$} & $0-400$ meter & 2 & \multirow{2}{*}{$\begin{array}{l}\text { SNI 03-1733- } \\
2004\end{array}$} \\
\hline & & $>400$ meter & 1 & \\
\hline \multirow[t]{8}{*}{ Aksesibilitas } & \multirow{2}{*}{ Kondisi jalan } & Baik (jalan halus, tidak berlubang/bergelombang) & 2 & \multirow{2}{*}{ Tamin (1997) } \\
\hline & & Buruk (jalan berlubang atau bergelombang) & 1 & \\
\hline & \multirow{2}{*}{ Perkerasan jalan } & Dengan perkerasan (aspal, beton, cor, paving) & 2 & \multirow{2}{*}{ Tamin (1997) } \\
\hline & & Tidak dengan perkerasan (tanah) & 1 & \\
\hline & \multirow[t]{2}{*}{ Ukuran jalan } & Dapat dilalui mobil dua arah & 2 & \multirow{2}{*}{ Tamin (1997) } \\
\hline & & Hanya dapat dilalui mobil satu arah & 1 & \\
\hline & \multirow[t]{2}{*}{ Waktu perjalanan } & $0-6,7$ menit & 2 & \multirow{2}{*}{ Carey (2005) } \\
\hline & & $>6,7$ menit & 1 & \\
\hline \multirow[t]{2}{*}{ Lingkungan } & \multirow[t]{2}{*}{ Kepadatan penduduk } & $0-200$ jiwa/ha & 2 & \multirow{2}{*}{$\begin{array}{l}\text { SNI 03-1733- } \\
2004\end{array}$} \\
\hline & & $>200$ jiwa/ha & 1 & \\
\hline
\end{tabular}

Setelah skor dari seluruh variabel diidentifikasikan, hasil skor kemudian dikalikan dengan bobot setiap variabel untuk setiap alternatif lokasi. Hasil tersebut kemudian akan menunjukkan kategori kesesuaian setiap alternatif lokasi sebagai lokasi parkir kawasan perdagangan Singosaren.

\section{HASIL DAN PEMBAHASAN}

\subsection{KEBUTUHAN RUANG PARKIR KAWASAN PERDAGANGAN SINGOSAREN}

Berdasarkan hasil survey patroli parkir dapat diketahui kebutuhan ruang parkir dengan mengalihkan akumulasi parkir maksimum dengan satuan ruang parkir, sehingga didapatkan hasil sebagai berikut :

Table 3. Luas Kebutuhan Ruang Parkir Kawasan Perdagangan Singosaren

\begin{tabular}{|c|c|c|c|c|c|}
\hline Lokasi Parkir & $\begin{array}{c}\text { Jenis } \\
\text { Kendaraan }\end{array}$ & $\begin{array}{c}\text { Akumulasi } \\
\text { Parkir Tertinggi }\end{array}$ & $\begin{array}{l}\text { Standar } \\
\text { SRP }\end{array}$ & $\begin{array}{l}\text { Kebutuhan Ruang } \\
\text { Parkir (c) } x(d) m^{2} \\
\end{array}$ & $\begin{array}{l}\text { Luas Kebutuhan } \\
\text { Ruang Parkir }\left(\mathrm{m}^{2}\right)\end{array}$ \\
\hline (a) & (b) & (c) & (d) & (e) & (f) \\
\hline \multirow[t]{3}{*}{ Jalan Gatot Subroto } & Motor & 474 & $0.75 \times 2.00$ & 711 & \multirow{3}{*}{1.546} \\
\hline & Mobil & 60 & $2.50 \times 5.00$ & 750 & \\
\hline & Truk/bus & 2 & $3.40 \times 12.50$ & 85 & \\
\hline \multirow{3}{*}{$\begin{array}{l}\text { Jalan Dr. Radjiman (ruas } \\
\text { 1) }\end{array}$} & Motor & 273 & $0.75 \times 2.00$ & 409,5 & \multirow{3}{*}{1.082} \\
\hline & Mobil & 47 & $2.50 \times 5.00$ & 587,5 & \\
\hline & Truk/bus & 2 & $3.40 \times 12.50$ & 85 & \\
\hline \multirow{3}{*}{$\begin{array}{l}\text { Jalan Dr. Radjiman (ruas } \\
\text { 2) }\end{array}$} & Motor & 163 & $0.75 \times 2.00$ & 244,5 & \multirow{3}{*}{2.632} \\
\hline & Mobil & 191 & $2.50 \times 5.00$ & $2.387,5$ & \\
\hline & Truk/bus & 0 & $3.40 \times 12.50$ & 0 & \\
\hline \multirow[t]{3}{*}{ Jalan Yos Sudarso } & Motor & 200 & $0.75 \times 2.00$ & 300 & \multirow{3}{*}{1.635} \\
\hline & Mobil & 83 & $2.50 \times 5.00$ & $1.037,5$ & \\
\hline & Truk/bus & 7 & $3.40 \times 12.50$ & 297,5 & \\
\hline \multicolumn{5}{|c|}{ Total kebutuhan ruang parkir pada seluruh kawasan } & $6.895 \mathrm{~m}^{2}$ \\
\hline
\end{tabular}

Sumber : Haqie, Fauzi Nuraninda, dkk.,2017

\subsection{BOBOT KRITERIA LOKASI PARKIR BERDASARKAN PREFERENSI PENGUNJUNG KAWASAN PERDAGANGAN SINGOSAREN}

Dari 96 responden didapatkan hasil bahwa pengunjung kawasan perdagangan Singosaren memilih keamanan sebagai kriteria paling penting dalam penentuan lokasi parkir. Tingkat kepentingan kedua adalah jarak berjalan. Tingkat 
kepentingan ketiga adalah aksesibilitas. Tingkat kepentingan keempat adalah ketersediaan lahan atau ruang. Tingkat kepentingan kelima adalah rencana tata ruang dan tingkat kepentingan paling rendah yaitu keenam adalah lingkungan.

Dari hasil rangking tersebut kemudian diolah kedalam rumus penentuan bobot yang telah disebutkan sebelumnya untuk mendapatkan bobot setiap kriteria. Bobot setiap kriteria tersebut sebagai berikut :
(1) Keamanan
$\rightarrow$ bobot 0,29
(2) Jarak berjalan
$\rightarrow$ bobot 0,24
(3) Aksesibilitas
$\rightarrow$ bobot 0,19
(4) Ketersediaan lahan atau ruang
$\rightarrow$ bobot 0,14
(5) Rencana tata ruang
(6) Lingkungan
$\rightarrow$ bobot 0,09
$\rightarrow$ bobot 0,05

\subsection{ALTERNATIF LOKASI PARKIR KAWASAN PERDAGANGAN SINGOSAREN}

Dari peta penggunaan lahan Kota Surakarta dan peta persebaran parkir off street di kawasan perdagangan Singosaren, didapatkan 4 lahan kosong dan 1 ruang yang dapat dimanfaatkan sebagai lokasi parkir. Lokasi tersebut dapat dilihat pada peta berikut.

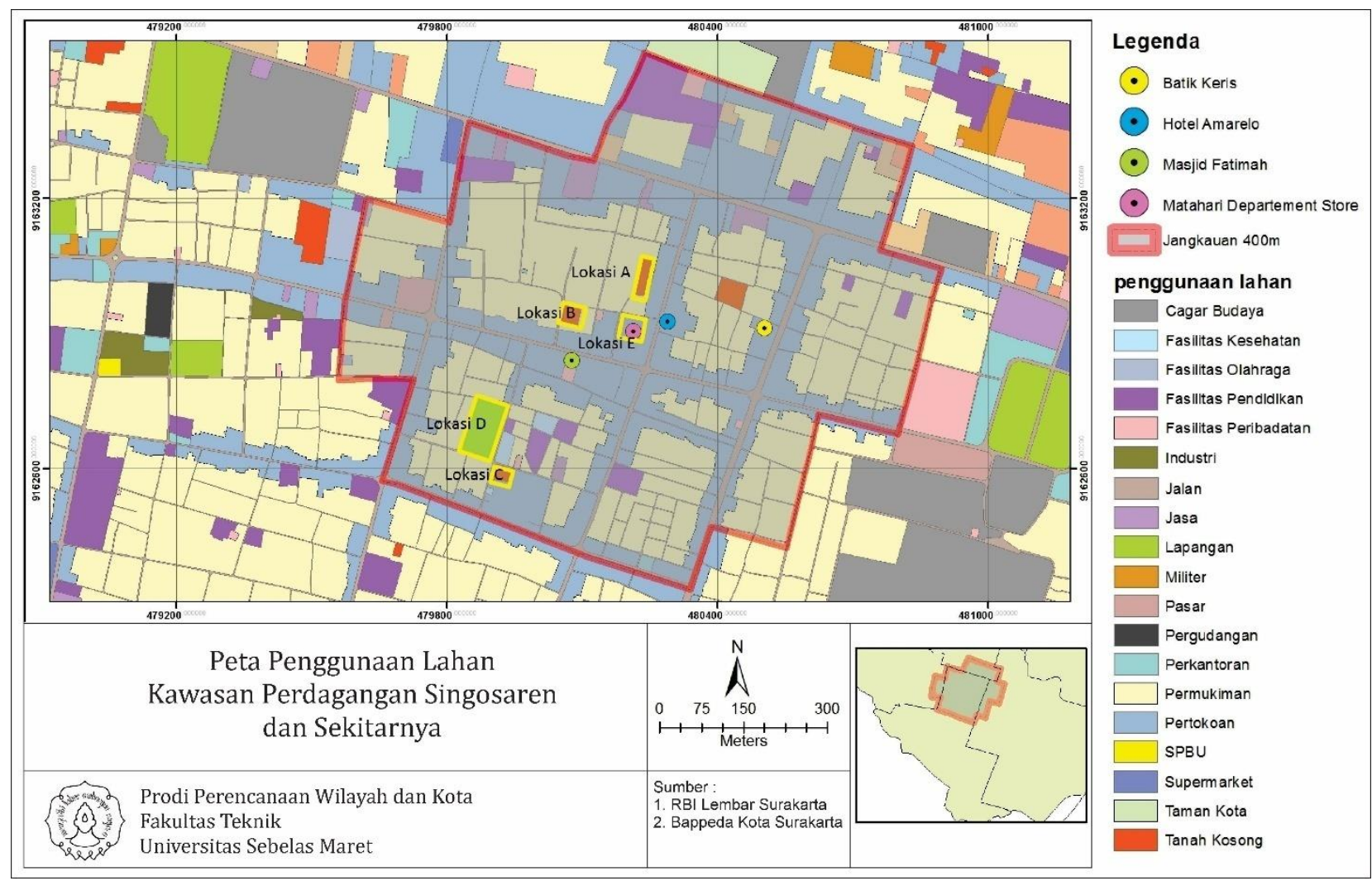

Gambar 1. Peta Penggunaan Lahan Kawasan Singosaren dan Sekitarnya

Selanjutnya untuk setiap alternatif lokasi akan dianalisis setiap kriteria yang ada untuk mendapatkan skor kesesuaian alternatif lokasi tersebut sebagai lokasi parkir. Berikut merupakan hasil dan pembahasan dari setiap alternatif lokasi parkir.

\section{a. Lahan Kosong Utara Matahahari Departement Store (Lokasi A)}

Lokasi A merupakan lahan kosong yang berada di utara Matahari Departement Store dengan luas $1813 \mathrm{~m}^{2}$. Dari hasil analisis setiap kriteria, didapatkan hasil sebagai berikut. 
Tabel 4. Hasil Analisis Lokasi A

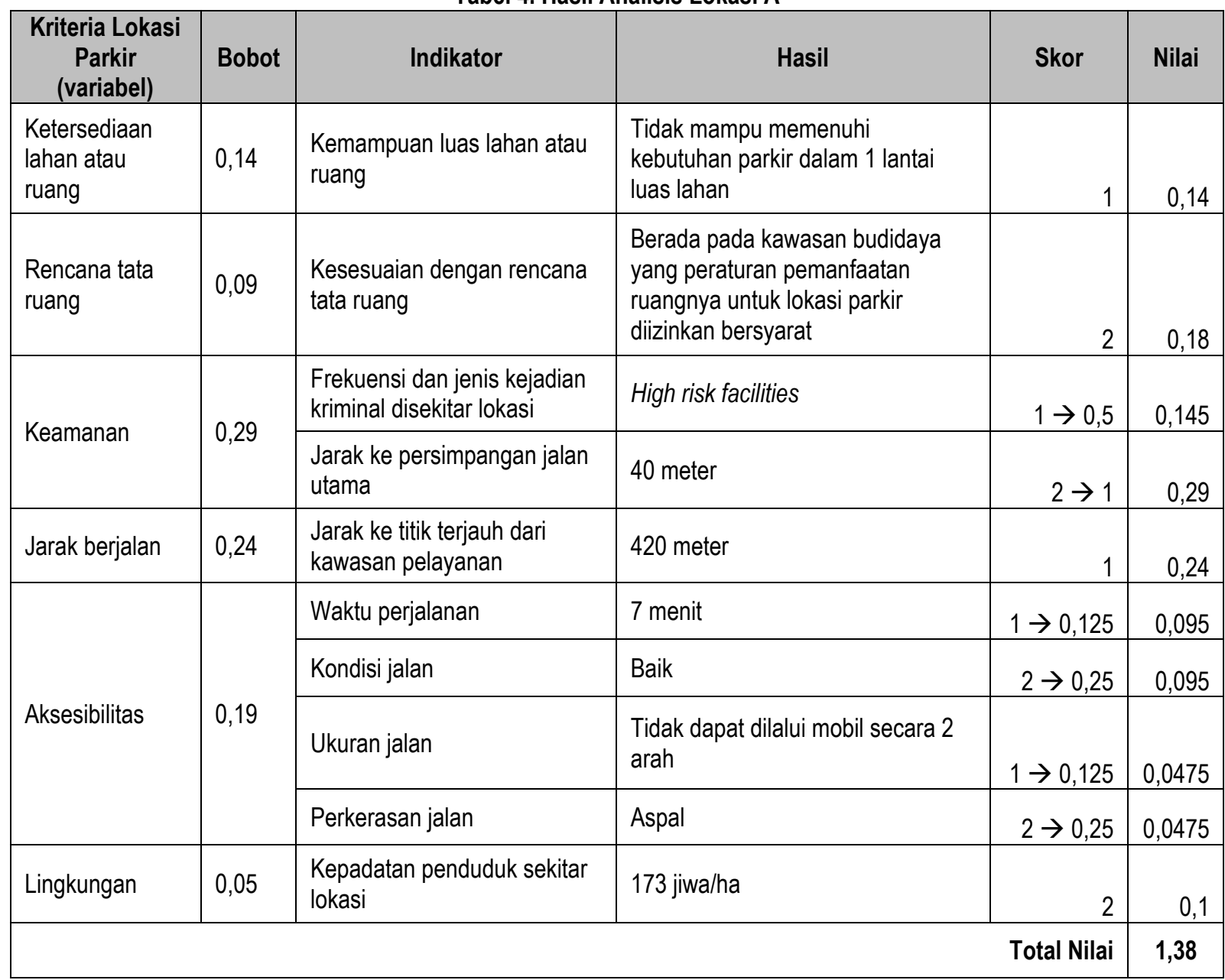

Sumber : Haqie, Fauzi Nuraninda, dkk., 2017

Dari hasil analisis, lokasi A akan melayani kebutuhan parkir dari Jalan Gatot Subroto, Yos Sudarso, Dr Radjiman 1 dan 2. Jarak lokasi A ke titik terjauh kawasan Gatot Subroto masih dalam jangkauan standar berjalan kaki yaitu 230 meter. Namun, untuk jarak titik terjauh pada Jalan Yos Sudarso yaitu 495 meter dan Dr. Radjiman yaitu 955 meter. Jarak ini tentu telah melebihi batas standar jarak berjalan kaki. Jarak yang terlalu jauh dapat menyebabkan orang enggan menggunakan fasilitas lokasi parkir tersebut. Hal ini sebenarnya dapat diantisipasi dan diimbangi dengan menciptakan ruang berjalan kaki yang menarik (terdapat atraksi dan aktivitas di dalamnya) dan nyaman, sehingga pengunjung tidak hanya sekedar berjalan kaki namun juga dapat menikmati atraksi yang ada sebagai hiburan. Terciptanya ruang pejalan kaki yang nyaman, aman, dan menarik ini sejalan dengan konsep walking street yang akan diterapkan pada perdagangan Singosaren.

Ditinjau dari aksesibilitasnya, lokasi A memiliki kelemahan dari aspek ukuran jalan. Ukuran jalan yang tidak dapat dilalui mobil secara 2 arah ini dapat mengurangi kelancaran sirkulasi kendaraan pada lokasi A. Ukuran jalan ini menjadi limitasi bagi lokasi A, karena jalan pada sekitar lokasi tersebut sudah tidak memungkinkan untuk dilakukan pelebaran jalan. Kondisi eksisting bangunan pada jalan tersebut memiliki tembok-tembok tinggi dan memiliki garis sempadan bangunan yang berimpit dengan garis sempadan jalan

Selain hal tersebut, lokasi $\mathrm{A}$ juga memiliki kelemahan pada keamanan dan kemampuannya dalam memenuhi kebutuhan parkir. Hal ini menyebabkan lokasi A masuk ke dalam kategori kurang sesuai sebagai lokasi parkir.

\section{b. Lahan Kosong Barat Matahahari Departement Store (Lokasi B)}

Lokasi B merupakan alternatif lokasi parkir yang berupa lahan kosong yang berada di barat Matahari Departement Store yangmemiliki luas $1871 \mathrm{~m}^{2}$. Dari hasil analisis setiap kriteria, didapatkan hasil sebagai berikut. 
Tabel 5. Hasil Analisis Lokasi B

\begin{tabular}{|c|c|c|c|c|c|}
\hline \\
\hline $\begin{array}{l}\text { Kriteria Lokasi } \\
\text { Parkir (variabel) }\end{array}$ & Bobot & Indikator & Hasil & Skor & Nilai \\
\hline $\begin{array}{l}\text { Ketersediaan } \\
\text { lahan atau ruang }\end{array}$ & 0,14 & $\begin{array}{l}\text { Kemampuan luas lahan atau } \\
\text { ruang }\end{array}$ & $\begin{array}{l}\text { Tidak mampu memenuhi kebutuhan } \\
\text { parkir dalam } 1 \text { lantai luas lahan }\end{array}$ & 1 & 0,14 \\
\hline $\begin{array}{l}\text { Rencana tata } \\
\text { ruang }\end{array}$ & 0,09 & $\begin{array}{l}\text { Kesesuaian dengan rencana } \\
\text { tata ruang }\end{array}$ & $\begin{array}{l}\text { Berada pada kawasan budidaya yang } \\
\text { peraturan pemanfaatan ruangnya } \\
\text { untuk lokasi parkir diizinkan bersyarat }\end{array}$ & 2 & 0,18 \\
\hline \multirow{2}{*}{ Keamanan } & \multirow{2}{*}{0,29} & $\begin{array}{l}\text { Frekuensi dan jenis kejadian } \\
\text { kriminal disekitar lokasi }\end{array}$ & Low risk facilities & $2 \rightarrow 1$ & 0,29 \\
\hline & & $\begin{array}{l}\text { Jarak ke persimpangan jalan } \\
\text { utama }\end{array}$ & 65 meter & $2 \rightarrow 1$ & 0,29 \\
\hline Jarak berjalan & 0,24 & $\begin{array}{l}\text { Jarak ke titik terjauh dari } \\
\text { kawasan pelayanan }\end{array}$ & 398,3 meter & 2 & 0,48 \\
\hline \multirow{4}{*}{ Aksesibilitas } & \multirow{4}{*}{0,19} & Waktu perjalanan & 6,6 menit & $2 \rightarrow 0,25$ & 0,095 \\
\hline & & Kondisi jalan & Baik & $2 \rightarrow 0,25$ & 0,095 \\
\hline & & Ukuran jalan & Dapat dilalui mobil secara 2 arah & $2 \rightarrow 0,25$ & 0,095 \\
\hline & & Perkerasan jalan & Aspal & $2 \rightarrow 0,25$ & 0,095 \\
\hline Lingkungan & 0,05 & $\begin{array}{l}\text { Kepadatan penduduk sekitar } \\
\text { lokasi }\end{array}$ & 97 jiwa/ha & 2 & 0,1 \\
\hline \multicolumn{5}{|c|}{ 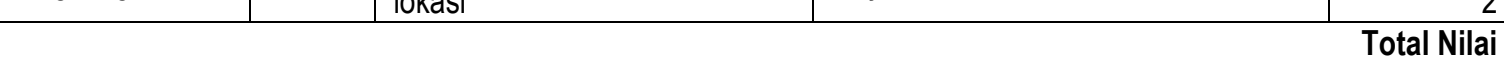 } & 1,86 \\
\hline
\end{tabular}

Sumber : Haqie, Fauzi Nuraninda, dkk.,2017

Kelemahan dari lokasi B adalah kemampuannya dalam memenuhi kebutuhan parkir. Dari hasil analisis, segmen pelayanan parkir lokasi B ditujukan untuk pengunjung pada kawasan Jalan Gatot Subroto, Jalan Yos Sudarso, dan Jalan Dr. Radjiman ruas 1. Dari segmen pelayanan tersebut lokasi memiliki kebutuhan ruang parkir yang harus ditampung sebesar $5260 \mathrm{~m}^{2}$, sehingga kebutuhan tersebut akan dapat ditampung lokasi B dalam lebih dari 1 lantai lahan. Hal ini dapat menyebabkan semakin lamanya waktu pengguna fasilitas parkir untuk mendapatkan ruang parkir (Teknomo, 1997). Untuk mengurangi lama waktu mendapatkan ruang parkir, dapat diminimalisir dengan penerapan sistem valet parkir. Sistem valet parkir dapat mempermudah pengguna parkir, karena pengguna cukup menyerahkan kendaraannya pada petugas parkir, kemudian petugas parkir yang akan mencarikan ruang parkir untuk kendaraan pengguna tersebut (O'Flaherty, 1997).

Selain dengan sistem valet parkir, dapat juga diterapkan teknologi parkir mekanis. Terdapat 2 jenis teknologi parkir mekanis, yaitu parkir mekanis biasa dan parkir mekanis penuh. Parkir mekanis biasa memiliki mekanisme yaitu kendaraan yang akan diparkir dikendarai diatas lift (pengendara tidak keluar dari kendaraan) kemudian lift akan berhenti pada lantai yang tersedia ruang parkir kosong, kemudian pengendara mengendarai mobilnya keluar dari lift dan menuju ruang parkir yang kosong. Sedangkan untuk parkir mekanis penuh memiliki mekanisme yaitu kendaraan yang akan diparkir diletakkan diatas lift (pengendara keluar dari kendaraan) kemudian lift akan berhenti pada lantai yang tersedia ruang parkir kosong dan lift akan bergerak secara horizontal untuk meletakkan kendaraan pada ruang parkir kosong tersebut. Teknologi ini dapat meningkatkan kapasitas ruang parkir karena menghilangkan jalan tangga dan tanjakan (Hobbs, 1995). Selain itu, gedung parkir mekanis juga dapat diterapkan pada lahan yang bernilai tinggi dan memiliki luasan terbatas karena efisiensinya dalam penggunaan ruang parkir. Namun teknologi ini juga memiliki kelemahan yaitu mahalnya biaya konstruksi dan perawatannya (O'Flaherty, 1997).

Lokasi B juga memiliki kesesuaian pada kriteria-kriteria laniinya yaitu keamanan, kemampuan dalam memenuhi kebutuhan parkir, jarak berjalan, aksesibilitas, rencana tata ruang, dan lingkungan. Hal ini membuat lokasi B menjadi sesuai sebagai lokasi parkir.

\section{c. Lahan Kosong Timur Lapangan Kartopuran (Lokasi C)}

Lokasi $\mathrm{C}$ merupakan alternatif lokasi parkir yang berupa lahan kosong yang berada di timur Lapangan Kartopuran dengan luas $1385 \mathrm{~m}^{2}$. Dari hasil analisis setiap kriteria, didapatkan hasil sebagai berikut. 
Tabel 6. Hasil Analisis Lokasi C

\begin{tabular}{|c|c|c|c|c|c|}
\hline $\begin{array}{l}\text { Kriteria Lokasi } \\
\text { Parkir } \\
\text { (Variabel) }\end{array}$ & Bobot & Indikator & Hasil & Skor & Nilai \\
\hline $\begin{array}{l}\text { Ketersediaan } \\
\text { lahan atau ruang }\end{array}$ & 0,14 & $\begin{array}{l}\text { Kemampuan luas lahan atau } \\
\text { ruang }\end{array}$ & $\begin{array}{l}\text { Tidak mampu memenuhi kebutuhan } \\
\text { parkir dalam } 1 \text { lantai luas lahan }\end{array}$ & 1 & 0,14 \\
\hline $\begin{array}{l}\text { Rencana tata } \\
\text { ruang }\end{array}$ & 0,09 & $\begin{array}{l}\text { Kesesuaian dengan rencana } \\
\text { tata ruang }\end{array}$ & $\begin{array}{l}\text { Berada pada kawasan budidaya yang } \\
\text { peraturan pemanfaatan ruangnya } \\
\text { untuk lokasi parkir diizinkan bersyarat }\end{array}$ & 2 & 0,18 \\
\hline \multirow[b]{2}{*}{ Keamanan } & \multirow[b]{2}{*}{0,29} & $\begin{array}{l}\text { Frekuensi dan jenis kejadian } \\
\text { kriminal disekitar lokasi }\end{array}$ & High risk facilities & $1 \rightarrow 0,5$ & 0,145 \\
\hline & & $\begin{array}{l}\text { Jarak ke persimpangan jalan } \\
\text { utama }\end{array}$ & 85 dan 200 meter & $2 \rightarrow 1$ & 0,29 \\
\hline Jarak berjalan & 0,24 & $\begin{array}{l}\text { Jarak ke titik terjauh dari } \\
\text { kawasan pelayanan }\end{array}$ & 360 meter & 2 & 0,48 \\
\hline \multirow{4}{*}{ Aksesibilitas } & \multirow{4}{*}{0,19} & Waktu perjalanan & 6 menit & $2 \rightarrow 0,25$ & 0,095 \\
\hline & & Kondisi jalan & Baik & $2 \rightarrow 0,25$ & 0,095 \\
\hline & & Ukuran jalan & Dapat dilalui mobil secara 2 arah & $2 \rightarrow 0,25$ & 0,095 \\
\hline & & Perkerasan jalan & Aspal & $2 \rightarrow 0,25$ & 0,095 \\
\hline \multirow[t]{2}{*}{ Lingkungan } & 0,05 & $\begin{array}{l}\text { Kepadatan penduduk sekitar } \\
\text { lokasi }\end{array}$ & 206 jiwa/ha & 1 & 0,05 \\
\hline & & & & Total Nilai & 1,67 \\
\hline
\end{tabular}

Sumber : Haqie, Fauzi Nuraninda, dkk.,2017

Salah satu kelemahan/ketidaksesuaian indikator lokasi $\mathrm{C}$ adalah kepadatan penduduk lingkungan sekitar lokasi C. Lokasi $\mathrm{C}$ berada pada kawasan yang memiliki kepadatan penduduk tinggi. Berada pada kawasan yang memiliki kepadatan penduduk tinggi, dikhawatirkan akan terjadi banyak resiko polusi akibat adanya kendaraan parkir yang dirasakan oleh warga sekitar lokasi. Hal ini dikarenakan kendaraan bermotor akan menghasilkan gas buang berupa NO, $\mathrm{HC}, \mathrm{CO}$, dan $\mathrm{CO}_{2}$. Gas buang ini akan menyebabkan polusi udara (Frey et al dalam Tsai dan Chu, 2011). Untuk mengurangi resiko polusi yang ditimbulkan oleh kendaraan parkir tersebut, dapat diimbangi dengan pemanfaatan beberapa tanaman. Tanaman yang dapat mereduksi kadar pencemaran udara diantaranya tanaman jenis pohon, tanaman perdu, dan tanaman semak (Kusminingrum dan Gunawan, 2008). Pada lingkungan sekitar lokasi C, hanya terlihat adanya tanaman jenis pohon. Keberadaannya pun tidak banyak, hanya pada titik-titik tertentu. Untuk itu keberadaan tanaman jenis pohon ini dapat ditingkatkan dan diimbangi dengan penambahan tanaman jenis perdu dan semak, sehingga penyerapan polusi dapat dimaksimalkan.

Selain itu, lokasi $\mathrm{C}$ juga memiliki kelemahan pada keamanan dan kemampuannya dalam memenuhi kebutuhan parkir. Namun, selain kelemahan tersebut, lokasi $\mathrm{C}$ juga masih memiliki kesesuaian pada kriteria-kriteria lainnya yaitu jarak berjalan, aksesibilitas, dan rencana tata ruang. Hal ini menjadikan lokasi $\mathrm{C}$ masih berada pada kategori sesuai sebagai lokasi parkir.

\section{d. Lapangan Kartopuran (Lokasi D)}

Lokasi D merupakan alternatif lokasi parkir yang berupa lapangan yaitu Lapangan Kartopuran dengan luas 9880 m² $^{2}$ Dari hasil analisis setiap kriteria, didapatkan hasil sebagai berikut.

Tabel 7. Hasil Analisis Lokasi D

\begin{tabular}{|c|c|c|c|c|c|}
\hline $\begin{array}{l}\text { Kriteria Lokasi } \\
\text { Parkir (variabel) }\end{array}$ & Bobot & Indikator & Hasil & Skor & Nilai \\
\hline $\begin{array}{l}\text { Ketersediaan } \\
\text { lahan atau ruang }\end{array}$ & 0,14 & $\begin{array}{l}\text { Kemampuan luas lahan atau } \\
\text { ruang }\end{array}$ & $\begin{array}{l}\text { Mampu memenuhi kebutuhan parkir } \\
\text { dalam } 1 \text { lantai luas lahan }\end{array}$ & 2 & 0,28 \\
\hline $\begin{array}{l}\text { Rencana tata } \\
\text { ruang }\end{array}$ & 0,09 & $\begin{array}{l}\text { Kesesuaian dengan rencana } \\
\text { tata ruang }\end{array}$ & $\begin{array}{l}\text { berada pada kawasan lindung yang } \\
\text { peraturan pemanfaatan ruangnya } \\
\text { untuk lokasi parkir tidak diizinkan }\end{array}$ & 1 & 0,09 \\
\hline \multirow{2}{*}{ Keamanan } & \multirow{2}{*}{0,29} & $\begin{array}{l}\text { Frekuensi dan jenis kejadian } \\
\text { kriminal disekitar lokasi }\end{array}$ & High risk facilities & $1 \rightarrow 0,5$ & 0,145 \\
\hline & & $\begin{array}{l}\text { Jarak ke persimpangan jalan } \\
\text { utama }\end{array}$ & $>25$ meter & $2 \rightarrow 1$ & 0,29 \\
\hline
\end{tabular}




\begin{tabular}{|l|l|l|l|r|r|}
\hline $\begin{array}{c}\text { Kriteria Lokasi } \\
\text { Parkir (variabel) }\end{array}$ & Bobot & \multicolumn{1}{|c|}{ Indikator } & \multicolumn{1}{|c|}{ Hasil } & \multicolumn{1}{c|}{ Skor } & Nilai \\
\hline \multirow{2}{*}{ Jarak berjalan } & 0,24 & $\begin{array}{l}\text { Jarak ke titik terjauh dari } \\
\text { kawasan pelayanan }\end{array}$ & 292,5 meter & 2 & 0,48 \\
\hline \multirow{3}{*}{ Aksesibilitas } & \multirow{2}{*}{0,19} & Waktu perjalanan & 4,9 menit & $2 \rightarrow 0,25$ & 0,095 \\
\cline { 3 - 6 } & & Kondisi jalan & Baik & $2 \rightarrow 0,25$ & 0,095 \\
\cline { 3 - 6 } & & Ukuran jalan & Dapat dilalui mobil secara 2 arah & $2 \rightarrow 0,25$ & 0,095 \\
\cline { 2 - 6 } & Perkerasan jalan & Aspal & $2 \rightarrow 0,25$ & 0,095 \\
\hline \multirow{2}{*}{ Lingkungan } & 0,05 & $\begin{array}{l}\text { Kepadatan penduduk sekitar } \\
\text { lokasi }\end{array}$ & 149 jiwa/ha & 2 & 0,1 \\
\hline
\end{tabular}

Sumber : Haqie, Fauzi Nuraninda, dkk.,2017

Salah satu indikator yang tidak sesuai dengan kriteria lokasi parkir adalah keseuaian Lokasi $D$ terhadap rencana tata ruang yang ada. Lokasi D yang berupa lapangan, dalam RDTR Kota Surakarta termasuk ke dalam kawasan lindung dengan rencana peruntukan sebagai ruang terbuka hijau. Selain itu, dalam peraturan pemanfaatan ruang tempat parkir umum yang berada pada kawasan lindung pemanfaatannya yaitu tidak diizinkan. Hal ini dikarenakan aktivitas parkir umum tidak sesuai dengan peruntukan lahan yang direncakan dan dapat menimbulkan dampak yang cukup besar bagi lingkungan. Ketidaksesuaian dengan rencana tata ruang sebenarnya menjadi hal yang mendasar dan dapat menjadi limitasi yang dapat menyebabkan lokasi $D$ secara otomatis menjadi tidak sesuai sebagai lokasi parkir walaupun hasil dari indikator lainnya menunjukkan kesesuaian dengan kriteria. Hasil total skor dari lokasi $D$ juga menunjukkan bahwa lokasi D masuk dalam kategori sesuai senagai alternatif lokasi parkir. Namun, hal ini dapat diatasi dengan intervensi dari pihak pemerintah. Apabila nantinya lokasi tersebut akan dimanfaatkan sebagai lokasi parkir (dengan mempertimbangkan hasil analisis bahwa lokasi tersebut sesuai apabila digunakan sebagai lokasi parkir menurut preferensi pengunjung), pemerintah dapat melakukan peninjauan kembali dengan dokumen rencana tata ruang yang ada. Alternatif lain yang dapat dilakukan adalah dengan mengadaptasi konsep ruang parkir yang ada di Kota Bandung. Kota Bandung memiliki lokasi parkir yang juga berada pada kawasan lindung ruang terbuka hijau/taman kota yaitu berada pada Alun-alun Bandung. Namun, lokasi parkir tersebut memanfaatkan ruang bawah tanah, sehingga lahan yang termasuk dalam kawasan lindung tersebut tetap dapat dimanfaatkan sebagai lokasi parkir dengan tidak mengganggu fungsi utama dari kawasan tersebut.

Selain kelemahan tersebut, lokasi $D$ juga memiliki kesesuaian pada kriteria-kriteria lainnya yaitu jarak berjalan, aksesibilitas, lingkungan, dan kemampuan dalam memenuhi kebutuhan parkir. Hal ini menjadikan lokasi D masuk pada kategori sesuai sebagai lokasi parkir.

\section{e. Ruang Parkir Matahahari Departement Store (Lokasi E)}

Lokasi E merupakan alternatif lokasi parkir yang berupa lahan kosong yang berada di ruang parkir Matahari Departement Store dengan luas $1764 \mathrm{~m}^{2}$. Dari hasil analisis setiap kriteria, didapatkan hasil sebagai berikut.

Tabel 8. Hasil Analisis Lokasi E

\begin{tabular}{|c|c|c|c|c|c|}
\hline $\begin{array}{l}\text { Kriteria Lokasi } \\
\text { Parkir (variabel) }\end{array}$ & Bobot & Indikator & Hasil & Skor & Nilai \\
\hline $\begin{array}{l}\text { Ketersediaan } \\
\text { lahan atau ruang }\end{array}$ & 0,14 & $\begin{array}{l}\text { Kemampuan luas lahan atau } \\
\text { ruang }\end{array}$ & $\begin{array}{l}\text { Tidak mampu memenuhi kebutuhan } \\
\text { parkir dalam } 1 \text { lantai luas lahan }\end{array}$ & 1 & 0,14 \\
\hline $\begin{array}{l}\text { Rencana tata } \\
\text { ruang }\end{array}$ & 0,09 & $\begin{array}{l}\text { Kesesuaian dengan rencana } \\
\text { tata ruang }\end{array}$ & $\begin{array}{l}\text { Berada pada kawasan budidaya yang } \\
\text { peraturan pemanfaatan ruangnya } \\
\text { untuk lokasi parkir diizinkan bersyarat }\end{array}$ & 2 & 0,18 \\
\hline \multirow{2}{*}{ Keamanan } & \multirow{2}{*}{0,29} & $\begin{array}{l}\text { Frekuensi dan jenis kejadian } \\
\text { kriminal disekitar lokasi }\end{array}$ & High risk facilities & $1 \rightarrow 0,5$ & 0,145 \\
\hline & & $\begin{array}{l}\text { Jarak ke persimpangan jalan } \\
\text { utama }\end{array}$ & 95 dan 55 meter & $2 \rightarrow 1$ & 0,29 \\
\hline Jarak berjalan & 0,24 & $\begin{array}{l}\text { Jarak ke titik terjauh dari } \\
\text { kawasan pelayanan }\end{array}$ & 366,3 meter & 2 & 0,48 \\
\hline \multirow{3}{*}{ Aksesibilitas } & \multirow{3}{*}{0,19} & Waktu perjalanan & 6,1 menit & $2 \rightarrow 0,25$ & 0,095 \\
\hline & & Kondisi jalan & Baik & $2 \rightarrow 0,25$ & 0,095 \\
\hline & & Ukuran jalan & Dapat dilalui mobil secara 2 arah & $2 \rightarrow 0,25$ & 0,095 \\
\hline
\end{tabular}




\begin{tabular}{|l|l|l|l|r|r|}
\hline $\begin{array}{l}\text { Kriteria Lokasi } \\
\text { Parkir (variabel) }\end{array}$ & Bobot & \multicolumn{1}{|c|}{ Indikator } & \multicolumn{1}{c|}{ Hasil } & \multicolumn{1}{c|}{ Skor } & \multicolumn{1}{c|}{ Nilai } \\
\hline & \multicolumn{1}{|c|}{ Perkerasan jalan } & Aspal & $2 \rightarrow 0,25$ & 0,095 \\
\hline Lingkungan & 0,05 & $\begin{array}{l}\text { Kepadatan penduduk sekitar } \\
\text { lokasi }\end{array}$ & 173 jiwa/ha & 2 & 0,1 \\
\hline \multicolumn{2}{|r|}{} & Total Nilai & 1,72 \\
\hline
\end{tabular}

Sumber : Haqie, Fauzi Nuraninda, dkk., 2017

Salah satu kelemahan dari lokasi E adalah tingkat keamanan lingkungan yang rendah. Kondisi tersebut diperlukan peningkatan keamanan pada lokasi E. Secara khusus melihat kondisi lokasi E yang berada pada department store, maka peningkatan keamanan dapat dilakukan dengan penambahan personil security dan pengaktifan kembali kegiatan pengamanan pada pos polisi di Matahari Departement Store. Pada Matahari Departement Store sebenarnya sudah Chrest et al (1996terdapat pos polisi dari Kepolisian Sektor Serengan, namun keberadaannya kini kurang optimal karena pos polisi tersebut lebih sering terlihat kosong tanpa ada personil pengamanan.

Sistem pencahayaan juga menjadi komponen penting dalam peningkatan keamanan lokasi parkir (Chrest et al, 1996). Untuk meningkatkan keamanan dan mencegah terjadinya tindak kriminalitas dapat digunakan lampu yang memiliki output cahaya berwarna puth. Lampu bercahaya putih ini memiliki tingkat kecerahan lebih terang daripada lampu yang memiliki output cahaya berwarna kuning. Salah satu jenis lampu tersebut adalah lampu LED. LED sangat direkomendasikan dan cocok untuk pencahayaan pada lokasi parkir. LED memiliki cahaya terang yang terdistribusi dengan baik dan lebih hemat energi sehingga lebih ramah lingkungan.

Selain kelemahan tersebut, lokasi E juga memiliki kesesuaian pada kriteria-kriteria lainnya yaitu jarak berjalan, aksesibilitas, lingkungan, dan rencana tata ruang. Hal ini menjadikan lokasi D masuk pada kategori sesuai sebagai lokasi parkir.

Mengingat bahwa keamanan merupakan kriteria paling penting dalam memilih lokasi parkir menurut preferensi pengunjung kawasan perdagangan Singosaren, maka secara umum, peningkatanan keamanan juga diperlukan pada alternatif lokasi lain yaitu lahan kosong utara Matahari Departement Store (lokasi A), lahan kosong timur Lapangan Kartopuran (lokasi C), dan Lapangan Kartopuran (lokasi D) karena pada lokasi tersebut juga memiliki resiko keamanan lingkungan high risk facilities. Peningkatan keamanan pada lokasi-lokasi tersebut dapat dilakukan dengan melibatkan peran aktif/intervensi pemerintah dengan menerapkan personil keamanan khusus pada lokasi-lokasi tersebut yang nantinya dapat digunakan sebagai lokasi parkir.

\section{KESIMPULAN}

Hasil dari penelitian ini yaitu didapatkan kriteria lokasi parkir yang baik menurut preferensi pengunjung kawasan perdagangan Singosaren dan alternatif lokasi parkir yang sesuai dengan kebutuhan pengunjung kawasan perdagangan Singosaren yang akan diterapkan konsep walking street. Untuk kriteria lokasi parkir yang baik menurut preferensi pengunjung kawasan perdagangan Singosaren didapatkan hasil yaitu urutan kriteria yang memiliki bobot paling tinggi kepentingannya hingga paling rendah adalah (1) keamanan; (2) jarak berjalan; (3) aksesibilitas; (4) ketersediaan lahan/ruang; (5) rencana tata ruang; (6) lingkungan.

Didapatkan pula 5 alternatif lokasi parkir untuk kawasan perdagangan Singosaren. Alternatif lokasi yang masuk dalam kategori sesuai adalah : (1) Lahan kosong barat Matahari Departement Store memiliki kelemahan yaitu tidak dapat memenuhi kebutuhan parkir dalam 1 luas lahan. (2) Lahan kosong timur Lapangan Kartopuran memiliki kelemahan yaitu tidak dapat memenuhi kebutuhan parkir dalam 1 luas lahan, keamanan lingkungan rendah, dan berada pada kawasan berkepadatan penduduk tinggi. (3) Lokasi Lapangan Kartopuran memiliki kelemahan yaitu terletak pada kawasan lindung yang pemanfaatannya sebagai lokasi parkir tidak diizinkan dan keamanan lingkungan yang rendah. (4) Ruang parkir Matahari Departement Store memiliki kelemahan yaitu tidak dapat memenuhi kebutuhan parkir dalam 1 luas lahan, dan keamanan lingkungan rendah. Kemudian, alternatif lokasi yang termasuk dalam kategori kurang sesuai sebagai lokasi parkir adalah lahan kosong utara Matahari Departement Store. Lahan kosong utara Matahari Departement Store memiliki kelemahan yaitu memenuhi kebutuhan parkir dalam 1 luas lahan, keamanan lingkungan rendah, jarak lokasi ke titik terjauh dari segmen pelayanannya lebih dari 400 meter; waktu perjalanan lebih dari 6,7 menit, dan ukuran jalan yang tidak dapat dilalui mobil secara 2 arah.

Rekomendasi : 
- Dari hasil analisis, 4 dari 5 alternatif lokasi memiliki kelemahan pada lingkungan yang memiliki tingkat keamanan rendah. Kemanan lingkungan menurut preferensi pengunjung kawasan perdagangan Singosaren merupakan kriteria paling penting dalam penentuan lokasi parkir. Untuk itu diperlukan peningkatan keamanan pada lingkungan sekitar alternatif lokasi yang memiliki keamanan lingkungan rendah, mengingat indikator tersebut merupakan indikator paling penting menurut pengunjung kawasan perdagangan Singosaren. Peningkatan keamanan lingkungan dapat dilakukan dengan intervensi pemerintah dalam penambahan personil keamanan pada alternatif lokasi parkir tersebut dan atau dengan meningkatkan kualitas dan kuantitas fasilitas penerangan pada lokasi parkir tersebut.

- Dapat dilakukan penerapan sitem pengelolaan perparkiran dan teknologi perparkiran untuk merespon setiap kelemahan dari setiap alternatif lokasi, sehingga fungsi dari lokasi tersebut sebagai lokasi parkir dapat dioptimalkan seiring dengan kelebihan-kelebihan yang dimiliki oleh setiap alternatif lokasi parkir yang didapatkan pada kawasan perdagangan Singosaren.

- Diperlukan investor untuk dapat mewujudkan lokasi parkir yang dilengkapi dengan penerapan teknologi perparkiran dan sistem pengelolaan perparkiran yang baik.

\section{DAFTAR PUSTAKA}

Carey, Nick. (2005). Establishing Pedestrian Walking Speeds. Portland : ITE Student Chapter Portland State University

Chrest, Anthony P, Mary S. Smith dan Sam Bhuyan. (1996). Parking Structures: Planning, Design, Construction, Maintenance and Repair (Second Edition). Dordrecht, Netherland: Springer Science Business Media, B.V.

Direktorat Jendral Perhubungan Darat. (1998). Pedomaman Perencanaan dan Pengoperasian Fasilitas Parkir.

Hobbs, F.D. (1995). Perencanaan dan Teknik Lalu Lintas. Yogyakarta: Gadjah Mada University Press

Kusminingrum, Nanny dan G. Gunawan. (2008). Polusi Udara Akibat Aktivitas Kendaraan Bermotor di Jalan Perkotaan Pulau Jawa dan Bali. Pusat Litbang Jalan dan Jembatan, 25(3), 77-89

Malczweski, Jacek. (1999). GIS and Multicriteria Decision Analysis. Toronto, Canada: John Wiley \& Sons

Miro, Fidel. (2012). Pengantar Sistem Transportasi.Jakarta: Erlangga

O'Flaherty, Coleman A. (1997). Transport Planning and Traffic Engineering. Oxford, U.K: Elsevier's Science and Technology Right Departement

Rencana Detail Tata Ruang Kawasan I Kota Surakarta

Rencana Detail Tata Ruang Kawasan II Kota Surakarta

Rochman, Tedy Arditya. (2013). Analisis Kebutuhan Parkir pada Jalan Provinsi Kota Surakarta tahun 2011. Surakarta: Universitas Sebelas Maret

Sinambela, Lijan Poltak. (2014). Metodologi Penelitian Kuantitatif (Untuk Bidang IImu Administrasi, Kebijakan Publik, Ekonomi, Sosiologi, Komunikasi dan IImu Sosial Lainnya). Yogyakarta: Graha IImu

SNI 03-1733-2004 tentang Tatacara Perencanaan Lingkungan Permukiman di Perkotaan

Sugiyono. (2013). Metode Penelitian Kuantitatif Kualitatif dan R\&D. Bandung: Alfabeta

Tamin, Ofyar Z. (1997).Perencanaan dan Permodelan Transportasi. Bandung: Penerbit ITB

Teknomo, Kardi dan Kazunori Hokao. (1997). Parking Behavior in Central Business District- A Case Study of Surabaya, Indonesia. EASTS, 2(2), 551-570.

Tsai, Mei-Ting dan Chih-Peng Chu. (2012). Evaluating Parking Reservation Policy in Urban Areas : Environmental Perspective. Transportation Research, Part D(17), 145-148.

Walking Street, Wajah Baru Kawasan Singosaren. Diakses Oktober 13, 2016 dari Koranjitu website, http://koranijtu.com/lifestyle. detail/3792/Walking.Street,.Wajah.Baru.Kawasan.Singosaren.html\&page=2

Whiteside, Robert E. (1961). Parking Garage Operation. New York: USA Library of Congress 